\title{
Effects of short-term hypoxia on metabolism and haemocyanin oxygen transport in the prawns Palaemon adspersus and Palaemonetes varians
}

\author{
Annemette Nielsen, Lars Hagerman* \\ Marine Biological Laboratory, Copenhagen University, Strandpromenaden 5, DK-3000 Helsingør, Denmark
}

\begin{abstract}
In summer, high temperatures are combined with severe nocturnal hypoxia in the shallow water of Danish fjords. Under these conditions, the prawns Palaemonetes varians (Leach) and Palaemon adspersus (Rathke) are spatially separated, with the former occupying the areas of highest temperature and lowest oxygen tension. If kept together, $P$. adspersus shows aggressive behaviour towards $P$. varians. Aerobic/anaerobic respiration and haemocyanin characteristics were measured in laboratory experiments $\left(24^{\circ} \mathrm{C}, 14 \mathrm{ppt}\right)$. Although the 2 species have similar metabolic rates, $P$. varians survives severe hypoxia better and has a lower $P_{c}$ (critical oxygen tension, below which respiration is partly or fully anaerobic) than $P$. adspersus. Both species accumulate high levels of lactate during anaerobiosis and remove it at similar rates. The haemocyanin concentration and total oxygen carrying capacity $(0.78$ $\pm 0.25 \mathrm{mmol} l^{-1}$ and $\left.2.25 \pm 0.56 \mathrm{vol} \%\right)$ of $P$. varians was higher than $P$. adspersus $\left(0.28 \pm 0.07 \mathrm{mmol} \mathrm{l}^{-1}\right.$ and $1.14 \pm 0.15$ vol\%). Haemocyanin oxygen affinity was always higher in $P$. varians regardless of $\mathrm{pH}$, but tile Bulu factor $(-i .44$ and -1.46$)$ and cooperativity $\left(n_{50}: 2.61 \pm 0.20\right.$ and $\left.2.82 \pm 0.49\right)$ were similar for $P$. varians and $P$. adspersus, respectively. $P$. varians is thus better adapted to severe hypoxia than $P$. adspersus.
\end{abstract}

KEY WORDS: Aerobic/anaerobic metabolism - Lactate Oxygen affinity

\section{INTRODUCTION}

Large fluctuations in water oxygen tension occur in shallow brackish waters on a diel basis, especially in areas with dense vegetation and a low degree of water mixing. Large variations in other physico-chemical parameters [temperature, salinity, $\mathrm{pH}, \mathrm{pCO}_{2}\left(\mathrm{CO}_{2}\right.$ partial pressure)] also take place in these waters (Ganning 1971, Morris \& Taylor 1983, Grieshaber et al. 1994). Such more or less regular changes in the physicochemical parameters challenge the physiological capacities of animals living in these habitats (Taylor 1990 , Grieshaber et al. 1994, Hagerman 1998), and it is of vital importance for the animals to possess the necessary behavioural and/or physiological adaptations Some of these might be enhanced blood-oxygen-transporting qualities, tolerance of high levels of anaerobic

•Addressee for correspondence. E-mail: mbllh@inet.uni2.dk metabolites, an enhanced ability for osmoregulation or tolerance of changes in internal ion concentrations, and a high degree of temperature tolerance.

The palaemonid prawn Palaemonetes varians is found typically in very shallow waters near freshwater outlets in Danish fjords (e.g. the Roskilde Fjord) (Rasmussen 1973). The related species Palaemon adspersus dominates in seagrass (Zostera marina) beds at ca 1 to $5 \mathrm{~m}$ depth (Rasmussen 1973); this species leaves the seagrass beds during the night and moves into more open or shallower areas to feed (Hagerman \& Østrup 1980). The 2 species are rarely observed together, even though their behaviour and ecology are very similar (Rasmussen 1973, Hagerman \& Uglow 1984). The somewhat smaller $P$. varians is probably excluded from the 'protected' $Z$. marina-areas by $P$. adspersus, which is aggressive towards $P$. varians when they are kept together in the laboratory (authors' unpubl. obs.). 
Palaemonetes varians migrates to shallow waters with low salinity and high summer temperatures, where they survive better than Palaemon adspersus due to a greater tolerance of low salinities at high temperatures (Hagerman \& Uglow 1983). There are also indications that $P$. varians is more able to tolerate periods of severe hypoxia (Hagerman \& Uglow 1984) and is possibly able to utilise low oxygen tensions better, by a more efficient uptake of oxygen across the gills and, perhaps, by having a higher haemolymph oxygen carrying capacity and a respiratory pigment with a higher affinity for oxygen.

The aim of the present work is to evaluate the respiratory physiology of Palaemonetes varians and Palaemon adspersus under conditions prevailing in shallow water during summertime in an attempt to explain their distributions.

\section{MATERIAL AND METHODS}

Palaemonetes varians and Palaemon adspersus were collected in the Roskilde Fjord area, west Zealand, Denmark. P. adspersus (mean wet weight $1.622 \pm 0.376 \mathrm{~g})$ were caught in prawn traps in the deeper part of the fjord. P. varians (mean wet weight $0.658 \pm 0.116 \mathrm{~g}$ ) were collected with a hand-held push-net in the innermost part of the fjord, close to the sluice leading to the Selsø lake. The prawns were transported to the Helsingør laboratory within a few hours and kept in $200 \mathrm{l}$ tanks with fully aerated running seawater (S: $32 \mathrm{ppt}_{i} \mathrm{~T}: 12^{\circ} \mathrm{C}$ ). The prawns were acclimated to laboratory conditions for at least $1 \mathrm{wk}$ before use. Prawns were fed regularly with fish pellets and minced meat of Mytilus edulis. All experimental prawns were acclimated to temperature $\left(24^{\circ} \mathrm{C}\right)$ and salinity $(14 \mathrm{ppt})$ in well-aerated water for at least $4 \mathrm{~d}$ before experiments. The prawns were not fed during this acclimation period. Only healthy intermoult prawns were used.

Field measurements. Diel variations in $\mathrm{pH}_{\text {, water }}$ $\mathrm{pO}_{2}$, temperature and salinity were measured every hour in shallow water $(0.5 \mathrm{~m})$ in May, June and August 1996 at 3 different places close to the sluice leading to the Selso lake. $\mathrm{pH}$ was measured with a combination $\mathrm{pH}$ electrode (PHC2005, Radiometer, Copenhagen, Denmark) connected to a portable pH meter (PHM80, Radiometer). Water temperature and $\mathrm{pO}_{2}$ were measured with an oxygen meter (Oxi96-B, WTW, Germany; or YSI58, Yellow Springs Instrument Co., Ohio, USA). Air temperature was measured in areas sheltered by trees close to the water's edge. Water samples, for salinity measurements, were brought back to the laboratory within 4 to $5 \mathrm{~h}$ and analysed with a refractometer (Atago Co., Tokyo, Japan).
Laboratory experiments. Aerobic metabolism was measured as oxygen consumption in a closed system. The respiration chamber was placed in an aquarium $\left(24^{\circ} \mathrm{C}, 14 \mathrm{ppt}\right)$ acting as water supply during the flushing periods and as a temperature bath. An oxygen electrode (E5047, Radiometer) was placed between the respiration chamber and a pump (Gilson minipuls3, USA) and connected to a computer via an oxygen meter (Radiometer PHM71 acid-base analyser with an $\mathrm{O}_{2}$ module PHA930). The oxygen tension in the chamber was recorded continuously during the experiments. Continuous water flow was provided by the Gilson pump to ensure a homogeneous oxygen distribution in the chamber and a continuous flow over the electrode. Respiration $\left(\mathrm{MO}_{2}\right.$ : weight specific respiratory rate) was measured on single individuals Due to the smaller size of Palaemonetes varians it was impossible to obtain individuals of both species within the same narrow weight range.

Prawns were allowed to acclimatise to the conditions within the chamber for 1 to $2 \mathrm{~h}$ until the respiratory rate was stable. During this period the chamber was flushed with well-aerated water. The experiments ran until the oxygen tension in the chamber had decreased below $5.3 \mathrm{kPa}$ or when the prawn appeared to be near death. All data (oxygen tension vs time) were corrected for electrode drift and the $\mathrm{MO}_{2}$ calculated after subtraction of the values of oxygen consumption recorded in controls run without prawns.

Anaerobic metabolism was studied by measurements of haemolymph lactate accumulation. After acclimation for $4 \mathrm{~d}$ to $24^{\circ} \mathrm{C}$ and $14 \mathrm{ppt}$, the prawns were transferred to a test aquarium with clean, well-aerated water $1 \mathrm{~d}$ before the experiment was carried out Hypoxia was achieved by bubbling $\mathrm{N}_{2}$ through the water; oxygen tension was regulated by a microprocessor-controlled regulator (constructed by Ejner Larsen, Århus University, Denmark) to $0.66 \mathrm{kPa}$ for Palaemonetes varians and $1.6 \mathrm{kPa}$ for Palaemon adspersus and monitored during the experiment with the same equipment as used for the respiration experiments. The difference in the oxygen tension chosen for the 2 species was based on the difference in $P_{c}$ (critical oxygen tension) found in the respiration experiments (see below). The tension chosen was well below the $P_{c}$ values recorded for each species. During the lactate accumulation experiments, individuals were removed for blood sampling at fixed time intervals. Each prawn was sampled only once. Blood samples were taken by penetrating the pericardium with a $0.1 \mathrm{ml}$ Hamilton hypodermic syringe and the volume of blood sampled was measured (40 to $70 \mu \mathrm{l}$ ). The blood was diluted immediately in $120 \mu \mathrm{l} 0.6 \mathrm{~N}$ perchloric acid and frozen at $-18^{\circ} \mathrm{C}$ prior to analysis. Lactate was measured on a spectrophotometer at $340 \mathrm{~nm}$ (Pharmacia Ultrospec II. 
Cambridge, England) with a L-lactic acid test-kit (no. 139 084, Boehringer-Mannheim).

The same procedure was used to measure the timedependent loss of lactate from the haemolymph due to oxidation or the formation of glycogen via gluconeogenesis after exposure to severe hypoxia for $5 \mathrm{~h}$ for Palaemonetes varians and $2 \mathrm{~h}$ for Palaemon adspersus. Blood sampling for these measurements began immediately after the oxygen tension was raised from hypoxic levels to normoxic tensions. The differences in the time that the prawns were exposed to hypoxia was necessary to ensure that sufficient lactate had accumulated in the haemolymph of $P$. varians.

In vivo haemolymph $p H$ was measured in individual prawns using a pH G299A electrode (BMSII, mk2, Radiometer) connected to a PHM73 Blood Gas Monitor (Radiometer). The polycarbonate capillary of the electrode was inserted directly into the pericardium of the prawn and the blood drawn directly into the electrode, thus avoiding any contact with air. The electrode was calibrated using Radiometer precision $\mathrm{pH}$ buffers.

Oxygen carrying capacity was calculated from haemocyanin (hc) concentrations measured on pooled haemolymph samples. The absorbance of $20 \mu \mathrm{l}$ haemolymph diluted in $400 \mathrm{\mu l}$ Tris-HCl buffer ( $\mathrm{pH}: 7.9)$ was measured at $335 \mathrm{~nm}$ using an UV-spectrophotometer (Pharmacia Ultrospec II). Hc concentration was calculated using an extinction coefficient $\varepsilon_{m m o l}^{\mathrm{cm}}$ of i $\overline{7} .26$ as applies to Carcinus maenas ho (Hagerman \& Weber 1981). Assuming haemolymph osmolarities equivalent to salinities of 23 and 25 ppt for Palaemonetes varians and Palaemon adspersus respectively (Potts \& Parry 1964, Hagerman \& Uglow 1979) and a barometric pressure of $101 \mathrm{kPa}$, the total oxygen-carrying capacity of the haemolymph was calculated by adding the physically dissolved oxygen to the calculated hc oxygen-carrying capacity.

Haemocyanin oxygen affinity: Pooled haemolymph samples were centrifuged in $1.5 \mathrm{ml}$ Eppendorf tubes for $5 \mathrm{~min}$ at $14000 \times \mathrm{g}$ and the supernatant used immediately for the construction of oxygen equilibrium curves (Weber \& Hagerman 1981). Oxygen equilibrium curves were constructed by stepwise oxygenation using a thin-layer technique (Sick \& Gersonde 1969). A small volume of sample $(5 \mu \mathrm{l}$ for Palaemonetes varians and $10 \mu \mathrm{l}$ for Palaemon adspersus, the difference was due to differences in the hc concentrations) was withdrawn from the supernatant and the oxygen equilibrium curves measured at $335 \mathrm{~nm}$ in a gas diffusion chamber (Eschweiler, Kiel, Germany) connected to a photometer (Eppendorf 1101M, Hamburg, Germany). The signal from the photometer was recorded on a potentiometric recorder via an antilogarithmic converter (Eschweiler). The appropriate gas mixtures were delivered by serially connected gas-mixing pumps (Wösthoff Digamix
SA27/3A and 2M201/a-F, Bochum, Germany) keeping constant $\mathrm{pCO}_{2}$ and increasing $\mathrm{pO}_{2}$ to obtain the different equilibration steps. Full oxygenation and de-oxygenation were measured after equilibration with $\mathrm{O}_{2}$ and $\mathrm{N}_{2}$ respectively at the beginning and end of each curve. At each step the haemolymph in the dif fusion chamber was allowed to equilibrate with the gas mixture for at least 20 min. Haemolymph $\mathrm{pH}$ was measured at several steps near half-saturation. A small volume of the pooled haemolymph sample was equilibrated to the appropriate gas mixture for $20 \mathrm{~min}$ and $\mathrm{pH}$ measured with a MI410 micro-combination electrode (Microelectrodes Inc., USA) connected to a PHM73 blood gas monitor (Radiometer).

Statistics: Differences between regression lines in the hc oxygen-affinity experiments were tested with comparisons of regression coefficients and analysis of covariance (ANCOVA). All other differences were tested with single classification of analysis of variance (ANOVA) (Sokal \& Rohlf 1981). Differences were considered significant if $\mathrm{p}<0.05$.

\section{RESULTS}

\section{Field measurements}

Temperature, water $\mathrm{pO}_{2}$ and $\mathrm{pH}$ showed large diel variations with high diurnal and low nocturnal values for all 3 sampling locations (Table 1). The largest fluctuations in all these parameters occurred in August when water temperatures were between 16.2 and $24.0^{\circ} \mathrm{C}$, oxygen tension of water $\left(P_{\mathrm{w}} \mathrm{O}_{2}\right)$ between 14.3 and $176.7 \%$ saturation and $\mathrm{pH}$ between 7.76 and 8.62 at location 3 . Salinity showed no diel variation.

\section{Laboratory measurements}

Aerobic and anaerobic metabolism. The critical oxygen tension $\left(P_{c}\right.$, below which declining $P_{\mathrm{w}} \mathrm{O}_{2}$ results in a decreased $\mathrm{MO}_{2}$ ) at $24^{\circ} \mathrm{C}$ and $14 \mathrm{ppt}$ was found to be $6.56 \pm 0.6 \mathrm{kPa}(\mathrm{n}=6)$ and $7.77 \pm 1.1 \mathrm{kPa}$ $(\mathrm{n}=9)$ for Palaemonetes varians and Palaemon adspersus, respectively. The differences in the $P_{\mathrm{c}}$ values were found to be significantly different $(\mathrm{p}<0.005)$. Routine metabolic rate at $P_{\mathrm{w}} \mathrm{O}_{2}>P_{\mathrm{c}}$ was found to be $0.166 \pm$ $0.034 \mathrm{mg} \mathrm{O}_{2} \mathrm{~h}^{-1} \mathrm{~g}^{-1}$ wet wt $(\mathrm{n}=6)$ and $0.163 \pm 0.035 \mathrm{mg}$ $\mathrm{O}_{2} \mathrm{~h}^{-1} \mathrm{~g}^{-1}$ wet wt $(\mathrm{n}=9)$ for $P$. varians and $P$. adspersus, respectively (Table 2 ).

Both species resorted to anaerobic metabolism when exposed to a $P_{\mathrm{w}} \mathrm{O}_{2}$ well below the $P_{\mathrm{c}}$. In Palaemonetes varians there was a tendency towards a lower lactate accumulation rate during the first 120 to $150 \mathrm{~min}$. In $P$. varians the maximum concentrations of haemolymph 
Table 1. Minimum and maximum values of some physico-chemical parameters during three $24 \mathrm{~h}$ periods at 3 locations (1 to 3) close to the sluice leading to the Selso lake, Roskilde Fjord, Denmark. $P_{\mathrm{w}} \mathrm{O}_{2}$ : oxygen tension of water

\begin{tabular}{|c|c|c|c|c|}
\hline \multicolumn{2}{|c|}{$\begin{array}{l}\text { Water temperature } \\
\left.\qquad{ }^{\circ} \mathrm{C}\right)\end{array}$} & $\begin{array}{c}P_{\mathrm{w}} \mathrm{O}_{2} \\
(\% \text { sat.) }\end{array}$ & $\mathrm{pH}$ & \multirow[t]{2}{*}{$\begin{array}{c}\text { Salinity } \\
\text { (ppt) }\end{array}$} \\
\hline May & & & & \\
\hline Location 1 & $10.3 \quad 17.6$ & $70 \quad 100$ & 7.968 .36 & 1717 \\
\hline Location 2 & 10.918 .6 & 61100 & $7.90 \quad 8.30$ & $-\quad-$ \\
\hline Location 3 & $11.0 \quad 17.5$ & 64100 & $7.88 \quad 8.26$ & $16 \quad 16$ \\
\hline \multicolumn{5}{|l|}{ June } \\
\hline Location 1 & 17.924 .1 & 39144 & 7.919 .06 & 1215 \\
\hline Location 2 & 18.824 .6 & 21160 & $7.96 \quad 8.70$ & 1415 \\
\hline Location 3 & 18.825 .0 & $42 \quad 167$ & $7.95 \quad 8.48$ & 1415 \\
\hline \multicolumn{5}{|l|}{ August } \\
\hline Location 1 & 16.525 .0 & $45 \quad 155$ & 7.998 .63 & $15 \quad 17$ \\
\hline Location 2 & 16.124 .9 & 26180 & 7.828 .76 & 1617 \\
\hline Location 3 & 16.224 .0 & $15 \quad 177$ & $7.76 \quad 8.62$ & 1617 \\
\hline
\end{tabular}

an appropriate number of blood samples. A lactate accumulation rate of $0.162 \mu \mathrm{mol} \mathrm{m} \mathrm{m}^{-1} \mathrm{~min}^{-1}$ was, however, calculated for $P$. adspersus for the 120 min of hypoxia that they survived. This rate was not significantly different from the value of $0.141 \mu \mathrm{mol} \mathrm{ml^{-1 }}$ $\min ^{-1}$ found for $P$. varians during the first hypoxic period, which increased to $0.272 \mu \mathrm{mol} \mathrm{ml} l^{-1} \mathrm{~min}^{-1}$ after $150 \mathrm{~min}$ of hypoxia (Table 2).

The time-dependent loss of haemolymph lactate in Palaemonetes varians and Palaemon adspersus (Fig. 1B) during normoxia following severe hypoxia showed a decrease of $0.162 \mu \mathrm{mol} \mathrm{ml} \mathrm{min}^{-1} \mathrm{~min}^{-1}$ for adspersus (although very few data could be obtained due to the high mortalities) lactate $\left(45.4 \mu \mathrm{mol} \mathrm{ml} \mathrm{m}^{-1}\right.$ ) were reached after ca $260 \mathrm{~min}$ of hypoxia (Fig. 1A). A high mortality of $P$. adspersus during the hypoxia exposure made it difficult to obtain

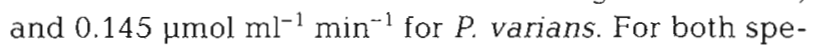
cies the rates of lactate loss were thus very similar to the lactate accumulation rates

Table 2. Palaemonetes varians and Palaemon adspersus. Summary of experimental results on respiratory physiology at $24^{\circ} \mathrm{C}$, and 14 ppt. $P_{c}$ : critical oxygen tension; $\mathrm{MO}_{2}$ : respiration; $P_{50}$ : haemocyanin oxygen affinity; and $n_{50}$ : cooperativity coefficient Statistics are shown as differences between the 2 species $(a: p<0.001 ; b: p<0.005 ;$ ns: no significant difference)

\begin{tabular}{|c|c|c|c|}
\hline Variable & $P$ varians & & P. adspersus \\
\hline$P_{c}(\mathrm{kPa})$ & $6.55 \pm 0.6$ & $b$ & $7.77 \pm 1.1$ \\
\hline $\mathrm{MO}_{2}\left(\mathrm{mg} \mathrm{O}_{2} \mathrm{~h}^{-1} \mathrm{~g}^{-1}\right.$ wet wt $)$ & $0.166 \pm 0.034$ & ns & $0.163 \pm 0.035$ \\
\hline Lactate accumulation rate $\left(\mu \mathrm{mol} \mathrm{ml} \mathrm{m}^{-1} \mathrm{~min}^{-1}\right)$ & 0.141 & ns & 0.162 \\
\hline 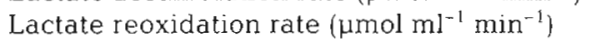 & 0.145 & ns & 0.162 \\
\hline Haemocyanin concentration $\left(\mathrm{mmol} \mathrm{l}^{-1}\right)$ & $0.776 \pm 0.252$ & $a$ & $0.282 \pm 0.068$ \\
\hline Haemocyanin $\mathrm{O}_{2}$ carrying capacity (vol\%) & $1.74 \pm 0.56$ & $a$ & $0.63 \pm 0.15$ \\
\hline Total $\mathrm{O}_{2}$ carrying capacity (vol $\%$ ) & $2.25 \pm 0.56$ & $a$ & $1.14 \pm 0.15$ \\
\hline In vivo $\mathrm{pH}$ & $7.438 \pm 0.074$ & ns & $7.427 \pm 0.111$ \\
\hline $\log P_{50}$ (dependence of $\mathrm{pH}$ ) & $-1.44 \times \mathrm{pH}+12.5$ & $b$ & $-1.46 \times \mathrm{pH}+12.81$ \\
\hline Bohr factor $\left(\Delta \log P_{50} / \Delta \mathrm{pH}\right)$ & -1.44 & ns & -1.46 \\
\hline$n_{50}$ & $2.61 \pm 0.20$ & ns & $2.82 \pm 0.49$ \\
\hline
\end{tabular}

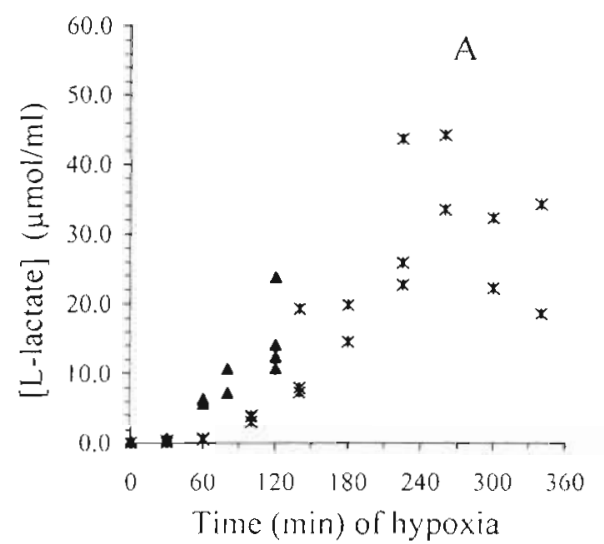

Time (min) of hypoxia

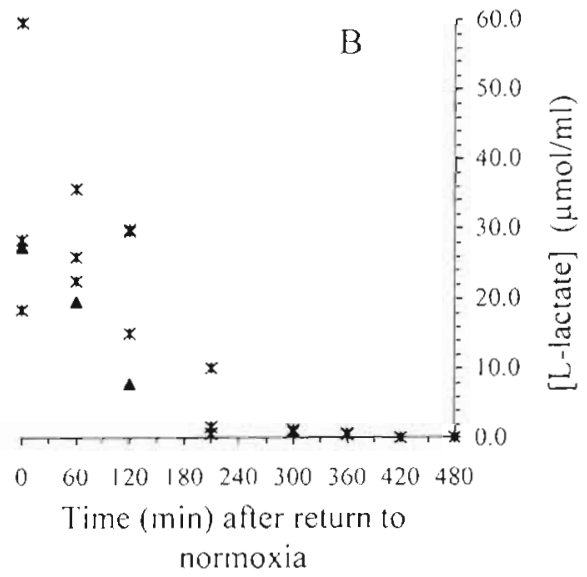

normoxia
Fig. 1 Palaemonetes varians and Palaemon adspersus. (A) Haemolymph lactate accumulation during exposure to severe hypoxia of $0.66 \mathrm{kPa}(x, P$. varians $)$ and $1.6 \mathrm{kPa}(\Lambda, P$. adspersus $)$ at $24^{\circ} \mathrm{C}$, and $14 \mathrm{ppt}$ (B) Haemolymph lactate reoxidation after return to normoxia symbols as in $(A)$ 
Fig. 2. Palaemonetes varians and Palaemon adspersus. (A) Haemocyanin oxygen affinity $\left(P_{50}\right)$ and cooperativity $\left(n_{50}\right)$ vs $\mathrm{pH}$ at $24^{\circ} \mathrm{C}$ and $14 \mathrm{ppt}$ in $P$. varians ( $*$ ) and $P$. adspersus (A). (B) Oxygen dissociation curves of haemocyamin at $24^{\circ} \mathrm{C}$ and $14 \mathrm{ppt}$ for $P$. varians (thick line) and $P$. adspersus (thin line). Curves are calculated from the $P_{50}$ values at the in vivo $\mathrm{pH}$ and the mean values of $n_{50}$
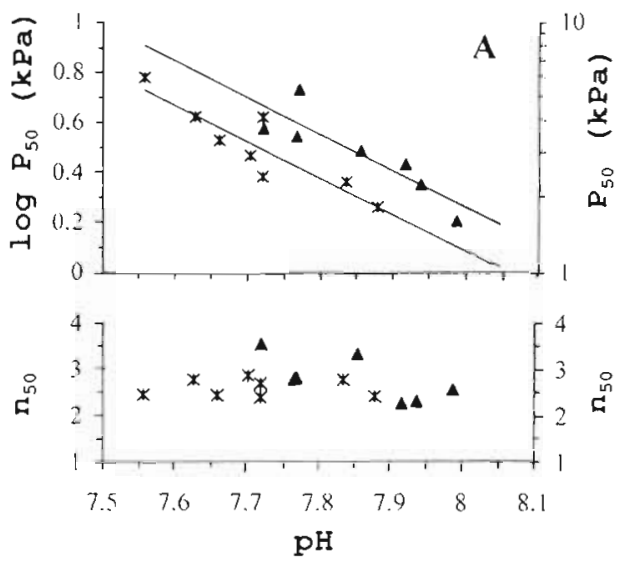

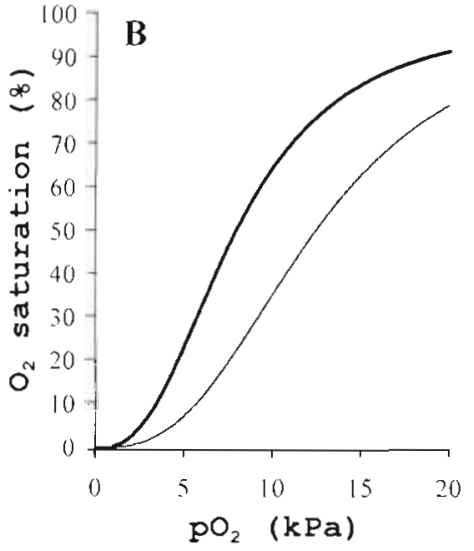

In vivo haemolymph $\mathrm{pH}$ was $7.44 \pm 0.07(\mathrm{n}=6)$ for Palaemonetes varians and $7.43 \pm 0.11(\mathrm{n}=7)$ for Paldemon adspersus (Table 2).

Oxygen carrying capacities were calculated from haemolymph hc concentrations, which were $0.78 \pm$ $0.25 \mathrm{mmol}^{-1}(\mathrm{n}=8)$ and $0.28 \pm 0.07 \mathrm{mmol} \mathrm{l}^{-1}$ for Palaemonetes varians and Palaemon adspersus, respectively. These values are significantly different $(\mathrm{p}<$ 0.001 ). The oxygen carrying capacities calculated from the hc concentrations correspond to $1.74 \pm 0.56 \mathrm{vol} \%$ and $0.63 \pm 0.15 \mathrm{vol} \%$, and when the physically dissolved oxygen is added this gives a total oxygen carrying capacity of $2.25 \pm 0.56$ vol\% for $P$. varians and 1.14 \pm 0.15 vol\% for $P$. adspersus.

Haemocyanin oxygen affinity $\left(P_{50}\right.$ : oxygen tension for half saturation of $h \mathrm{c}$ ) and the cooperativity coefficient $\left(n_{50}\right)$ in relation to $\mathrm{pH}$ are shown in Fig. $2 \mathrm{~A}$, and oxygen dissociation curves calculated at in vivo $\mathrm{pH}$ for both species are shown in Fig. 2B. Palaemonetes varians he shows a significantly higher affinity for oxygen than $P$. adspersus. Bohr factors $\left(\Delta \log P_{50} / \Delta \mathrm{pH}\right)$ were large, -1.44 for $P$. varians and -1.46 for $P$. adspersus. $\log P_{50}$ was found to be significantly higher $(\mathrm{p}<0.005)$ for $P$. adspersus regardless of $\mathrm{pH}$, i.e. there is a higher haemocyanin oxygen affinity in $P$. varians. The $n_{50}$ values were similar in the 2 species, $2.61 \pm 0.20(\mathrm{n}=8)$ in $P$. varians and $2.82 \pm 0.49(n=7)$ in $P$. adspersus.

\section{DISCUSSION}

The diel fluctuations in physico-chemical parameters in the shallow waters at the Selso sluice locality were large, especially with regard to $P_{w} \mathrm{O}_{2}$ and $\mathrm{pH}$, the latter reflecting variations in $P_{\mathrm{w}} \mathrm{CO}_{2}\left(\mathrm{CO}_{2}\right.$ tension of water $)$ with low diurnal and high nocturnal values. The changes are typical for shallow, sheltered areas and rock pools (Ganning 1971. Truchot \& Duhamel-Jouve 1980, Morris \& Taylor 1983). In all 3 field sampling periods, the weather was a little windy, so fluctuations in these parameters may be expected to be even larger in calm weather. This highly variable environment, and especially the high water temperatures, requires special adaptations from organisms living there. Palaemonetes varians can thus be expected to have the physiological adaptations typical for species of highly variable environments, while Palaemon adspersus, living in a less variable environment, might not be expected to have such a high degree of physiological adaptability.

Palaemonetes varians was shown to have a significantly lower $P_{c}$ than Palaemon adspersus, but this value is considerably higher than the values (1 3$2.6 \mathrm{kPa}$ at $20^{\circ} \mathrm{C}$ ) found in an earlier study of $P$. varians (Hagerman \& Uglow 1984). The higher temperature decreases the concentration of oxygen and increases the metabolic rate, shifting $P_{\mathrm{c}}$ towards a higher value (Herreid 1980). The shore crab Carcinus maenas, for example, increased its $P_{c}$ by $2.6 \mathrm{kPa}$ when the temperature was increased from 10 to $18^{\circ} \mathrm{C}$ (Taylor et al. 1977). Such interspecific differences in $P_{c}$ were also noted for the intertidal (rock-pool) Palaemon elegans compared with the subtidal Palaemon longirostris and Palaemon serratus (Taylor \& Spicer 1989, Taylor 1990). The non-significant difference in metabolic rates is possibly due to a better metabolic regulation of the smaller $P$. varians at high temperatures, as also noted for $P$. vulgaris by McFarland \& Pickens (1965).

During severe experimental hypoxia $(1.6$ and $0.66 \mathrm{kPa}$ for Palaemon adspersus and Palaemonetes varians, respectively) at $24^{\circ} \mathrm{C}, P$. varians survived considerably longer, although oxygen tension was lower. Both species change their metabolism to anaerobic glycolysis with lactate as the end product under severe hypoxia/anoxia, and haemolymph lactate accumulation rates can be used as a measure of anaerobic metabolism (Gäde 1983). Lactate accumulation rates for the 2 species were the same, probably due to the difference in experimental $P_{\mathrm{w}} \mathrm{O}_{2}$, i.e. their metabolism may have been only partly anaerobic. Taylor \& Spicer 
(1987) found a lower lactate accumulation rate at a $P_{\mathrm{w}} \mathrm{O}_{2}$ of $1.3 \mathrm{kPa}$ than of $0.66 \mathrm{kPa}$ in Palaemon elegans. The concentrations of haemolymph lactate after the hypoxic period were high in both species compared to the lactate concentrations in $P$. elegans and $P$. serratus at 0.66 and $1.3 \mathrm{kPa}$, respectively (Taylor \& Spicer 1987). The rates found for both species in the present investigation are similar to the lactate accumulation rate found for Crangon crangon at $1.1 \mathrm{kPa}$ (Hagerman \& Szaniawska 1986, Hagerman \& Vismann 1995).

Both Palaemonetes varians and Palaemon adspersus remove lactate at approximately the same rate as they accumulate it. This has been observed in a number of decapods, such as the related Palaemon elegans (Bridges \& Brand 1980, Taylor \& Spicer 1987). Some crustacean species, e.g. Galathea strigosa and Homarus gammarus, have, however, a considerably lower rate of lactate removal than accumulation (Bridges \& Brand 1980). The lactate reoxidises to pyruvate and can enter the citric acid cycle, some might also be used in gluconeogenesis (Bridges \& Brand 1980, Stryer 1988). The fraction used for gluconeogenesis varies between species and this might account for interspecific variations in lactate removal rates. It has been suggested that species most likely to encounter environmental hypoxia are better adapted physiologically to remove accumulated lactate on the return to normoxic conditions (Bridges \& Brand 1980 Grieshaber et al. 1994, Astall et al. 1997, Hagerman 1998).

The lower $P_{c}$ for Palaemonetes varians indicates an enhancement in the oxygen-transporting properties of the hc compared to that of Palaemon adspersus. The former species had a significantly higher hc oxygencarrying capacity and thereby also a higher total haemolymph oxygen carrying capacity. In earlier works, $P$. adspersus was found to have a higher oxygen carrying capacity (Hagerman \& Weber 1981, Weber \& Hagerman 1981) than in the present study. Haemocyanin concentration can show large fluctuations between populations in relation to factors such as season, salinity and the nutritional state of the animal (Taylor 1990, Truchot 1992), and this might be the reason for the noted discrepancies in hc concentrations. Other palaemonid prawns have hc values intermediate to those found here (Taylor \& Spicer 1989).

The in vivo haemolymph pH values were very low for both species, but such low values have been reported for a few reptant decapods at high salinities and high temperatures (Weiland \& Mangum 1975, Truchot 1978,1992$)$. Even if handling stress was minimised it cannot be totally excluded and this might contribute to a low haemolymph $\mathrm{pH}$.

The hc of Palaemonetes varians had a higher oxygen affinity than did the hc of Palaemon adspersus; $P_{50}$ was lower for $P$. varians at all in vitro $\mathrm{pH}$ values measured. The $\mathrm{P}_{50}$ values and the Bohr shifts found are within the ranges typical for palaemonid prawns at this temperature, and the lower $P_{50}$ for $P$. varians compared to $P$. adspersus is what might be expected for a species more tolerant of both the frequency and duration of severe hypoxia (Taylor 1990, Truchot 1992). A large normal Bohr shift will enhance oxygen affinity during hypoxia, due to initial hyperventilation resulting in an increase in haemolymph $\mathrm{pH}$ (Truchot 1975). During prolonged severe hypoxia with partly aerobic metabolism, however, lactate production and the associated acidification of the haemolymph will decrease hc oxygen affinity. Even if lactate per se will counteract this decrease slightly (Truchot 1980) a deoxygenation of hc would occur and thereby transfer the last hc-bound oxygen reserve to the tissues.

Temperature, salinity and low oxygen are important environmental factors that contribute to the spatial demarcation of the habitats of marine species. All factors are believed to restrict the distribution of Palaemon adspersus in shallow and sheltered waters during the warm summer months. The metabolic and respiratory adaptations found in the present study clearly show that Palaemonetes varians is physiologically better adapted than $P$. adspersus to survive periodic hypoxia during summertime. The high temperatures and low oxygen tensions recorded in shallow water in the Danish fjord are thus not a problem for $P$. varians. The higher carrying capacity and stronger oxygen affinity will enhance the uptake of oxygen during hypoxia, making it possible for this species to survive, while $P$. adspersus has to migrate to deeper, colder water. $P$. varians also shows more pronounced behavioural adaptations to hypoxia. Both in the laboratory and in the field $P$. varians could often be seen to adopt an inverted position at the water surface during periods of low water oxygen tension. In this way, the prawns are able to ventilate their gills with water that can be expected to have a higher oxygen tension than water deeper in the water column. Hagerman \& Uglow (1984) also noted that during hypoxia P. varians jumped out of the water and for a short time adhered to plants etc. Taylor \& Spicer (1988) noted also that during severe hypoxia, Palaemon elegans exhibited a partial emersion response, remaining quiescent at the air water interface.

Acknowledgements. The project was supported by The Carlsberg Foundation and by the Danish Science Research Council, grant no. 11-8391/0088. Dr Bent Vismann kindly gave instructions on the use of the computer set-up for respiration measurements. 


\section{LITERATURE CITED}

Astall CM, Taylor AC, Atkinson RJA (1997) Behavioural and physiological implications of a burrow-dwelling lifestyle for two species of Upogebiid mud-shrimp (Crustacea: Thalassinidea). Estuar Coast Shelf Sci 44:155-168

Bridges CR, Brand AR (1980) The effect of hypoxia on oxygen consumption and blood lactate levels of some marine crustacea. Comp Biochem Physiol 65A:399-409

Gäde G (1983) Energy metabolism of arthropods and molluscs during environmental and functional anaerobiosis. J Exp Biol 228:415-429

Ganning B (1971) Studies on chemical, physical and biological conditions in Swedish rock-pool ecosystems. Ophelia 9:51-105

Grieshaber MK, Hardewig I, Kreutzer U, Pörtner HO (1994) Physiological and metabolic responses to hypoxia in invertebrates. Rev Physiol Biochem Pharmacol 125:44-147

Hagerman L (1998) Physiological flexibility; a necessity for life in anoxic and sulphidic habitats. Hydrobiologia (in press)

Hagerman L, Østrup J (1980) Seasonal and diel activity variations in the shrimp Palaemon adspersus from a brackish, non-tidal area. Mar Ecol Prog Ser 2:329-335

Hagerman L, Szaniawska A (1986) Behaviour, tolerance and anaerobic metabolism under hypoxia in the brackishwater shrimp Crangon crangon. Mar Ecol Prog Ser 34: $125-132$

Hagerman L, Uglow RF (1979) Heart and scaphognathite activity in the shrimp Palaemon adspersus (Rathke). Ophelia 18:89-96

Hagerman L, Uglow RF (1983) The influence of temperature on the osmoregulation of the brackish water shrimp Palaemonetes varians (Leach). Ophelia 22:229-236

Hagerman L, Uglow RF (1984) The influence of hypoxia on the blood regulation of the brackish water shrimp Palaemonetes varians (Leach). J Exp Mar Biol Ecol 76:157-165

Hagerman L, Vismann B (1995) Anaerobic metabolism in the shrimp Crangon crangon exposed to hypoxia, anoxia and hydrogen sulfide. Mar Biol 123:235-240

Hagerman L, Weber RE (1981) Respiratory rate, haemolymph oxygen tension and haemocyanin level in the shrimp Palaemon adpsersus (Rathke). J Exp Mar Biol Ecol 54:13-20

Herreid CF (1980) Hypoxia in invertebrates. Comp Biochem Physiol 67A:311-320

McFarland WN, Pickens PE (1965) The effects of season, temperature and salinity on standard and active oxygen consumption of the grass shrimp. Palaemonetes vulgaris (Say). Can J Zool 43:571-585

Morris S, Taylor AC (1983) Diurnal and seasonal variations in physico-chemical conditions within intertidal rock pools. Estuar Coast Shelf Sci 17:339-355

Editorial responsibility: Tom Fenchel (Contributing Editor), Helsinger, Denmark
Potts WTW, Parry G (1964) Sodium and chloride balance in the prawn, Palaemonetes varians. J Exp Biol 41:591-601

Rasmussen E (1973) Systematics and ecology of the Isefjord marine fauna (Denmark). Ophelia 11:3-495

Sick H, Gersonde K (1969) Method for continuous registration of $\mathrm{O}_{2}$-binding curves of hemoproteins by means of a diffusion chamber. Anal Biochem 32:362-376

Sokal RR, Rohlf FJ (1981) Biometry, 2nd edn. WH Freeman and Company, New York

Stryer L (1988) Biochemistry, 3rd edn. WH Freeman and Company, New York

Taylor AC (1990) Respiratory responses to environmental conditions in intertidal prawns. In: Truchot JP, Lahlou B (eds) Animal nutrition and transport processes. 2. Transport, respiration and excretion: comparative and environmental aspects. Comp Physiol Basel, Karger 6:104-118

Taylor AC, Spicer JI (1987) Metabolic responses of the prawns Palaemon elegans and P. serratus (Crustacea: Decapoda) to acute hypoxia and anoxia. Mar Biol 95:521-530

Taylor AC, Spicer Jl (1988) Functional significance of a partial-emersion response in the intertidal prawn Palaemon elegans (Crustacea: Palaemonidae) during environmental hypoxia. Mar Ecol Prog Ser 44:141-147

Taylor AC, Spicer JI (1989) Interspecific comparison of the respiratory response to declining oxygen tension and the oxygen transporting properties of the blood of some Palaemonid prawns (Crustacea: Palaemonidae). Mar Behav Physiol 14:81-91

Taylor EW, Butler PJ, Al-Wassia A (1977) Some responses of the shore crab, Carcinus maenas (L.), to progressive hypoxia at different acclimation temperatures and salinities. J Comp Physiol 122:391-402

Truchot JP (1975) Changements de l'état acide-base du sang en fonction de l'oxygénation de l'eall chez le crabe Carcinus maenas (L.). J Physiol Paris 70:583-592

Truchot JP (1978) Mechanisms of extracellular acid-base regulation as temperature changes in decapod crustaceans. Respir Physiol 33:161-176

Truchot JP (1980) Lactate increases the oxygen affinity of crab hemocyanin. J Exp Zool 214:205-208

Truchot JP (1992) Respiratory function of arthropod haemocyanins. Adv Comp Environ Physiol 13:377-410

Truchot JP, Duhamel-Jouve A (1980) Oxygen and carbon dioxide in the marine intertidal environment: diurnal and tidal changes in rockpools. Respir Physiol 39:241-254

Weber RE, Hagerman L (1981) Oxygen and carbon dioxide transporting qualities of hemocyanin in the hemolymph of a natant decapod Palaemon adspersus. J Comp Physiol 145:21-27

Weiland AL, Mangum CP (1975) The influence of environmental salinity on hemocyanin function in the blue crab, Callinectes sapidus. J Exp Zool 193:265-274

Submitted: February 5, 1998; Accepted: March 23, 1998 Proofs received from author(s): May 22, 1998 